\title{
The Ameliorative Effect of Propolis Extract (bee glue) Against Oxidative Damage Induced by Methotrexate in Rats
}

\author{
Fatma Abd EL-Hamid Khalil, Amal Ashmawy Ahmed, Enas Ali Kamel and Nourhan Gamal \\ EL-Rahmany \\ Biochemistry and Nutrition Department, \\ Faculty of Women for Arts, Science and Education, Ain Shams University, Cairo, Egypt.
}

\begin{abstract}
Methotrexate (MTX) is an anti-folate used to treat cancer and some inflammatory diseases. The efficacy of MTX is often limited by its severe toxicity. Propolis is one of the most significant bee products that has an important role in balancing antioxidant systems and has an anti-peroxidant effect on several tissues. The present study was conducted to investigate the ameliorative effect of propolis against the methotrexate induced oxidative damage on blood, liver and kidney in rats. A total of one hundred and twenty male Wistar albino rats of mean body weights $90 \pm 5 \mathrm{~g}$ were divided into 5 groups. Rats were administered their respective doses of propolis and/or MTX for 3, 6 and 9 weeks intervals. Control groups $\left(G_{1}\right.$ and $\left.G_{2}\right)$, propolis group $\left(\mathrm{G}_{3}\right)$, methotrexate group $\left(\mathrm{G}_{4}\right)$ and methotrexate and propolis co-administered group $\left(\mathrm{G}_{5}\right)$. The results showed that the MTX significant reduced hemoglobin concentration, hematocrit \%, MCHC value, RBCs, WBCs and platelets count and significantly increased MCV and lymphocytes \%. Moreover, it caused a significant increase in MDA level and significant decrease in GSH concentration in liver tissue as compared to normal control group $\left(\mathrm{G}_{1}\right)$ in a time dependent manner. MTX administration also caused significant increase in serum AST, ALT and ALP activities in a time dependent manner, but a significant increase in total bilirubin only in 9 weeks as compared to normal control $\left(\mathrm{G}_{1}\right)$. On the other hand, MTX impaired kidney function as reflected by a significant increase in serum urea and creatinine levels and decrease in serum uric acid level as compared to normal control group. Results suggest that administration of propolis extract $\left(\mathrm{G}_{5}\right)$ help reduce the deleterious effects due to MTX injection in a time dependent manner, whereas, administration for 9 weeks offers better alleviation over 6 or 3 weeks. Data showed that long term administration of MTX for 9 weeks produce maximum damage over 6 or 3 weeks. Propolis extract administration also recovered the structural and functional integrity of the hepatic cells.
\end{abstract}

Key words: Methotrexate, Propolis extract, Oxidative damage, Liver function, kidney function Antioxidant system, Rats.

\section{Introduction}

Methotrexate (MTX) is widely used as a cytotoxic chemotherapeutic agent to treat various neoplastic diseases such as acute lymphoblastic leukemia, lymphoma, solid cancers and autoimmune diseases such as psoriasis and rheumatoid arthritis. It has the potential to generate free radicals, and such free radicals could precipitate oxidative stress especially in the presence of insufficient endogenous antioxidant enzymes within the biological system.

Corresponding author: Nourhan.gamal@women.asu.edu.eg. Mobile: 01007606821 
However, the efficacy of this agent often is limited by severe side effects and toxic sequelae. Since, the cytotoxic effect of MTX is not selective for the cancer cells; it also affects the normal tissues. MTX administration has been reported to cause acute renal failure, hepatotoxicity characterized by necrosis and fibrosis, neurotoxicity, hematologic and intestinal mucosa oxidative stress. Patients taking methotrexate are more likely to discontinue therapies because of the adverse effects of medication rather than lack of efficacy (Sener et al., 2006) and (Mohamed and Metwally, 2009).

Some drugs may enhance or inhibit the activities of enzymes needed for nutrient metabolism. The drug MTX, which acts by interfering with folate metabolism and thus depriving rapidly dividing cancer cells of folate they need to multiply. MTX resembles folate in structure and competes with folate for the enzyme that converts folate to its active form. The adverse effects of using methotrexate therefore include symptoms of folate deficiency (De Bruyne and Pinna, 2013).

MTX-induced toxicity appears to be a consequence of the interaction of many factors: dosing schedule and length of treatment, patients' risk factors, type of disease, and presence of genetic and molecular apoptotic factors (Krajinovic and Moghrabi, 2004). The nutritional approach by supplementing or supporting the body with natural phytochemicals cannot only reduce adverse side effects but also improve the effectiveness of chemotherapeutics (Sak, 2012).

Propolis is a resinous material collected by bees from bud and exudates of the plants and is transformed by bee enzymes. Bees use the propolis (bee glue) along with bees wax to construct their hives. Bees use it to seal holes in their honeycombs, smooth out internal walls as well as to cover carcasses of intruders who died inside the hive in order to avoid their decomposition. Propolis also protects the colony from diseases because of its antiseptic efficacy and antimicrobial properties (Najaf et al., 2007).

Chemical analysis of propolis has pointed to the presence of at least 300 compounds in its composition. It is mainly composed of resin (50\%), wax (30\%), essential oils (10\%), pollen (5\%), and other organic compounds (5\%) (Russo et al., 2002). Among these organic compounds, phenolic compounds and esters, flavonoids in all their forms (flavonoles, flavones, flavonones, dihydroflavonoles, and chalcones), terpenes, beta-steroids, aromatic aldehydes and alcohols, sesquiterpenes, and stilbene terpenes. Its composition varies with different factors, such as source of the exudates, climate, and environmental conditions. At least 38 flavonoids have been found in propolis, including galagin, kaempferol, quercetin, pinocembrin, pinostorbin, chyrisin, narinigen and pinobanksin. Other important elements present in propolis include calcium, manganese, magnesium, zinc, copper, silicon and iron. Propolis is also rich in pro-vitamin A ( $\beta$-carotene), vitamin $\mathrm{A}$ (retinol), vitamins $\mathrm{B}_{1}, \mathrm{~B}_{2}, \mathrm{~B}_{5}, \mathrm{~B}_{6}, \mathrm{C}, \mathrm{E}, \mathrm{D}$ and also proteins and carbohydrates (Kędzia, et al., 2009). Latterly, propolis has gained popularity in connection with oxidative stress and used widely in healthy drinks and foods to recuperate health and prevent diseases such as inflammation, heart disease, diabetes and even cancer (Tatli-Seven et al., 2009). Propolis presents a plenty of biological and pharmacological properties, such as immuno-modulatory, antitumor, anti-inflammatory, antioxidant, 
antibacterial, antiviral, antifungal, anti-parasitic activities, among others. These properties of propolis are based on its rich, flavonoid, phenolic acid and terpenoid contents (Sforcin and Bankova, 2011).

It's likely that the presence of a large number of compounds in propolis may produce a synergistic effect greater than the sum of the effects of individual components (Tatli-Seven et al., 2009). Caffeic acid phenethyl ester (CAPE) is extensively used in oxidative stress related researches. CAPE, is one of the major components of honeybee propolis, it can be speculated that CAPE may affect the transcriptional and/or translational pathways of these antioxidant enzymes. Another explanation for this effect of CAPE may be that it prevents the induction of the enzymes by the inhibition of toxic oxidative products the inhibition of ROS formation by propolis and its components provides a potential molecular basis for the protective actions of propolis not only through the retardation of NF-KB activation, inhibition of eicosanoid synthesis, and reduction in expression of various inflammatory cytokines in the nucleus, but also through the inhibition of oxidative damage to proteins, lipids, DNA/RNA and carbohydrates (El-Masry et al., 2011) and (Farooqui and Farooqui, 2010). This study aimed to investigate the modulatory effect of propolis against oxidative damage of methotrexate.

\section{Materials and Methods}

\section{Materials}

Ethyl Alcohol (95\%) and dimethyl sulphoxide (DMSO) were purchased from ElGomhoria Company for chemicals and drugs, Cairo, Egypt. Propolis (PP) was purchased from the faculty of agriculture, Cairo University, Giza, Egypt. Methotrexate drug (MTX) was obtained from Orion Corporation. Finland.

\section{Preparation of Propolis extract:}

The extract of dried, milled Propolis was prepared by soaking $10 \mathrm{~g}$ in hydroalcoholic mixture (30\% water and 70\% ethanol) for three days in a dark place according to Sforcin et al. (2002). After filtration, the extraction solvent was evaporated under vacuum by a rotary evaporator at $40^{\circ} \mathrm{C}$ and the solvent was removed. The obtained viscous residue was dissolved in DMSO as a vehicle for propolis.

\section{Animals and experimental design:}

In the present study, one hundred twenty male Wistar albino rats, weighing $90 \pm 5 \mathrm{~g}$ were used in this study. Animals were obtained from the animal house of Helwan-Farm, Cairo, Egypt. Rats were housed individually in animal care facility with constant environment in controlled stainless steel cages, under a room temperature $\left(25^{\circ} \mathrm{C} \pm 5^{\circ} \mathrm{C}\right)$, relative humidity $(50 \% \pm 10 \%)$, with 12 hour light/dark cycles. Animals were allowed seven days preexperimentation period to be adapted to the laboratory conditions. Rats were allowed to a standard commercial pellets diet, diet according to NRC (1995). Throughout the experiment and water was given ad libitum. Rats were randomly divided into five groups with 8 rats in each. Rats were weighed every other day and accordingly, the dose of PP and MTX were adjusted. Propolis was administered orally at a dose (200 mg/kg b.wt. twice/week) using intra- 
gastric tube. Methotrexate was injected intra-peritoneal at a dose $(2.5 \mathrm{mg} / \mathrm{kg}$ b.wt. single dose/week) throughout the experimental periods (3,6 and 9 weeks). The groups were as the following:

Group 1: Healthy rats fed on the standard commercial diet (control group).

Group 2: Healthy rats fed on the standard commercial diet, injected with saline and orally administered DMSO (Saline + DMSO group).

Group 3: Healthy rats fed on the standard commercial diet and orally administered propolis extract (PP group).

Group 4: Rats fed on the standard commercial diet and injected with methotrexate (MTX group).

Group 5: Rats fed on the standard commercial diet and injected with methotrexate and orally administered propolis extract (MTX + PP group).

After 3, 6 and 9 weeks, the rats were sacrificed after 12 hour fasting. The blood samples were taken from hepatic portal vein into two tubes: the first tube contained ethylenediamine-tetra-acetic acid (EDTA) for blood picture determination .The second tube was left for 15 minutes at $37{ }^{\circ} \mathrm{C}$, then centrifuged at 4000 r.p.m for 20 minutes. Serum was separated and kept at $-20^{\circ} \mathrm{C}$ until analysis. Liver was removed and washed twice with ice cold saline solution. Liver tissue was stored at $-20^{\circ} \mathrm{C}$ for estimation of various biochemical parameters. Parts of liver were kept in $10 \%$ formalin solution for histopathological examination and then liver tissue sections were stained with Hemato-xylin and Eosin.

\section{Biochemical analysis:}

Hemoglobin concentration $(\mathrm{Hb})$, hematocrit $(\mathrm{Hct}) \%$, mean corpuscular volume (MCV), mean corpuscular hemoglobin concentration (MCHC), erythrocytes count (RBCs), platelets count, white blood cells count (WBCs) and lymphocytes \% were assayed using an automatic cell counter (dirui BCC3000B, X123000BBCC0114, China).

Glutathione reduced (GSH) activity and malondialdehyde (MDA) were determined in liver homogenate using colorimetric method, kits developed by the Biodiagnostic and Ben Italy company respectively according the procedure of Beutler et al., (1963) and Ohkawa et al., (1979) respectively. Serum activities of aspartate aminotransferase (AST) and alanine aminotransferase (ALT) and alkaline phosphatase (ALP) were determined using the colorimetric method according to the kits developed by Bio STC company and procedure described by Henry, (1974 a, b) and Belfield and Goldberg (1971) respectively. Total bilirubin was determined in serum according to the colorimetric method, kits from Salucea company as described by Malloy and Evelyn (1937). Serum uric acid and creatinine levels were determined by enzymatic colorimetric method from Vitro Scient as described by Gochman and Schmitz (1971) and Rock et al. (1987) respectively. Serum urea level was performed by enzymatic colorimetric method according to Tobacco et al. (1979) by kits performed from Diamond company. 


\section{Statistical analysis:}

Results are expressed as mean \pm SD. The data were statistically analyzed following the one way analysis of variance [ANOVA, F test and least significant difference (L.S.D)] at (P < 0.05) were carried out using the statistical package for social science (SPSS) version 17.0 followed by Dunnett's multiple comparisons test to compare all the groups.

\section{Results and Discussion:}

Chemotherapeutic drugs are often associated with some degrees of toxicities, which are coursed by reactive metabolites generated by the biotransformation of anticancer drugs in the liver (Moreira et al., 2011). Toxicity often limits the usefulness of anticancer agents being also the reason why many patients discontinue the treatment (Sak, 2012).

While the cytotoxic effect of MTX is not selective for cancer cells, it also affects the normal tissues which have a high rate of proliferation, including the hematopoetic cells in the bone marrow and actively dividing cells of the intestinal mucosa (Kovacic and Somanathan, 2008). Recent reports suggest that propolis may have an important role in balancing antioxidant systems and has an antiperoxidant effect on several tissues, which may account for its beneficial effect in oxidant induced injury (Bhadauria et al., 2008).

From the results obtained in table (1\& 2), MTX caused significant reduction in hemoglobin concentration, MCHC, hematocrit values, platelets, RBCs and WBCs count in MTX group. Moreover, MTX caused relative increase in MCV and lymphocyte percentage $(\mathrm{p}<0.05)$ as compared to control group. The results of Ulrich et al. (2001) are similar to the results of the current study who reported that the most important potential side-effect of methotrexate is myelosuppression, it causes profound suppression of the bone marrow. Which is characterized by anemia (reduced hematocrit, hemoglobin and number of red blood cells), leucopoenia (reduced number of white blood cells) and thrombocytopenia (reduced number of platelets).

Also, Şener et al. (2006) and Çetin et al. (2008) reported that MTX treatment caused significant reductions in hemoglobin and hematocrit values and diminished numbers of red and white blood cells and platelets while relative increase in lymphocyte percentage was observed. Haematological parameters should be monitored during therapy because the occurrence of neutropenia and thrombocytopenia can limit the dose administered or obligate the cessation of MTX therapy (Juntti-Patinen et al., 2006). Consumption of propolis extract $\left(G_{5}\right)$ reversed the alterations induced by MTX in all of these hematological parameters to be near normal control levels. The amelioration caused was time dependent as 9 weeks treatment with propolis was more effective compared with 6 or 3 weeks treatment. The improvement may be due to propolis induced extensive proliferation of hematopoietic cells in the spleen and bone marrow. Moreover, it improves the digestive utilization of iron and increases the regeneration efficiency of hemoglobin especially during recovery from an anemic syndrome. In addition, the high 
content of flavonoids in propolis improves the expression level of erythropoietin hormone (EPO) and accelerates the generation of erythrocyte and hemoglobin (Abu Aita et al., 2012).

Table (1): Hb concentration (g/dl), Hct \%, MCV (fl) and MCHC in the studied rats groups:

\begin{tabular}{|c|c|c|c|c|c|c|}
\hline \multirow{2}{*}{ 爮 } & \multirow[b]{2}{*}{$\frac{n}{d}$} & \multicolumn{5}{|c|}{ Groups } \\
\hline & & $\begin{array}{l}\text { Healthy control } \\
\text { (G1) }\end{array}$ & $\begin{array}{c}\text { Saline + DMSO } \\
\text { (G 2) }\end{array}$ & $\begin{array}{l}\text { PP group } \\
\text { (G 3) }\end{array}$ & $\begin{array}{l}\text { MTX group } \\
\text { (G4) }\end{array}$ & $\begin{array}{c}\text { MTX + PP } \\
\text { group } \\
\text { (G5) }\end{array}$ \\
\hline \multirow{3}{*}{$\hat{I}$} & 3 & $12.59 \pm 0.36^{\mathrm{a}, 1}$ & $12.60 \pm 0.40^{\mathrm{a}, 1}$ & $12.83 \pm 0.92^{\mathrm{a}, 1}$ & $8.7 \pm .0 .32^{\mathrm{c}, 1}$ & $9.66 \pm 0.19^{b, 3}$ \\
\hline & 6 & $12.67 \pm 0.52^{a, 1}$ & $12.56 \pm 0.80^{\mathrm{a}, 1}$ & $12.83 \pm 0.57^{\mathrm{a}, 1}$ & $7.42 \pm 0.22^{c, 2}$ & $10.66 \pm 0.43^{b, 2}$ \\
\hline & 9 & $12.78 \pm 0.91^{\mathrm{a}, 1}$ & $12.46 \pm 0.50^{\mathrm{a}, 1}$ & $12.59 \pm 0.65^{\mathrm{a}, 1}$ & $6.53 \pm 0.19^{c, 3}$ & $11.04 \pm 0.09^{\mathrm{b}, 1}$ \\
\hline \multirow{3}{*}{ 岂 } & 3 & $32.66 \pm 0.36^{\mathrm{a}, 1}$ & $32.56 \pm 0.42^{\mathrm{a}, 1}$ & $32.70 \pm 0.42^{\mathrm{a}, 1}$ & $25.24 \pm 0.91^{\mathrm{c}, 1}$ & $27.22 \pm 0.33^{\mathrm{b}, 3}$ \\
\hline & 6 & $32.61 \pm 0.43^{a, 1}$ & $32.76 \pm 0.46^{\mathrm{a}, 1}$ & $32.78 \pm 0.39^{\mathrm{a}, 1}$ & $22.25 \pm 0.54^{\mathrm{c}, 2}$ & $28.28 \pm 1.31^{\mathrm{b}, 2}$ \\
\hline & 9 & $32.65 \pm 0.25^{\mathrm{a}, 1}$ & $32.64 \pm 0.59^{\mathrm{a}, 1}$ & $32.61 \pm 0.35^{\mathrm{a}, 1}$ & $20.5 \pm 0.70^{c, 3}$ & $29.59 \pm 0.37^{\mathrm{b}, 1}$ \\
\hline \multirow{3}{*}{ 己 } & 3 & $54.07 \pm 1.06^{\mathrm{b}, 1}$ & $54.04 \pm 0.68^{b, 1}$ & $54.16 \pm 1.21^{\mathrm{b}, 1}$ & $60.73 \pm 3.84^{\mathrm{a}, 2}$ & $61.85 \pm 3.59^{\mathrm{a}, 1}$ \\
\hline & 6 & $53.4 \pm 2.01^{\mathrm{c}, 1}$ & $53.64 \pm 1.88^{\mathrm{c}, 1}$ & $53.88 \pm 1.80^{\mathrm{c}, 1}$ & $65.26 \pm 3.01^{\mathrm{a}, 2}$ & $60.06 \pm 3.08^{\mathrm{b}, 1}$ \\
\hline & 9 & $53.40 \pm 0.99^{\mathrm{c}, 1}$ & $53.72 \pm 2.28^{\mathrm{c}, 1}$ & $54.04 \pm 1.01^{\mathrm{c}, 1}$ & $68.08 \pm 1.74^{a, 1}$ & $60.05 \pm 2.07^{\mathrm{b}, 1}$ \\
\hline \multirow{3}{*}{ 结 } & 3 & $38.54 \pm 0.91^{\mathrm{a}, 1}$ & $38.75 \pm 1.25^{\mathrm{a}, 1}$ & $39.26 \pm 2.99^{\mathrm{a}, 1}$ & $35.24 \pm 0.63^{b, 1}$ & $35.44 \pm 0.71^{\mathrm{b}, 2}$ \\
\hline & 6 & $38.86 \pm 1.65^{\mathrm{a}, 1}$ & $38.38 \pm 2.83^{\mathrm{a}, 1}$ & $39.15 \pm 1.98^{a, 1}$ & $33.39 \pm 0.48^{\mathrm{b}, 2}$ & $38.06 \pm 2.48^{a, 1}$ \\
\hline & 9 & $39.18 \pm 3.04^{\mathrm{a}, 1}$ & $38.30 \pm 1.65^{\mathrm{a}, 1}$ & $38.62 \pm 2.12^{a, 1}$ & $32.17 \pm 1.15^{\mathrm{b}, 3}$ & $37.59 \pm 0.45^{\mathrm{a}, 1}$ \\
\hline
\end{tabular}

$\mathrm{Hb}$, hemoglobin; Hct, hematocrit; MCHC, mean corpuscular hemoglobin concentration; MCV, mean corpuscular volume.

$>$ Values are expressed as mean \pm S.D, $n=8$

$>$ There was no significant difference between means have the same alphabetical superscripts (a, b, c, d and e) in the same row.

$>$ There was no significant difference between means have the same numerical value superscripts $(1,2,3)$ in the same column. 
Table (2): platelet count, lymphocyte \%, WBCs count $\left(x 10^{3} / \mu L\right)$ and $R B C s$ count $\left(x 10^{6} / \mu L\right)$ in the studied rats groups:

\begin{tabular}{|c|c|c|c|c|c|c|}
\hline \multirow{2}{*}{ 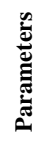 } & \multirow{2}{*}{ 党 } & \multicolumn{5}{|c|}{ Groups } \\
\hline & & $\begin{array}{l}\text { Healthy control } \\
\text { (G1) }\end{array}$ & $\begin{array}{c}\text { Saline }+\underset{\text { DMSO }}{\text { D }}(\mathbf{G} \\
\end{array}$ & $\begin{array}{l}\text { PP group } \\
\text { (G 3) }\end{array}$ & $\begin{array}{l}\text { MTX group } \\
\text { (G4) }\end{array}$ & $\begin{array}{c}\text { MTX + PP group } \\
\text { (G5) }\end{array}$ \\
\hline \multirow{3}{*}{$\begin{array}{l}\frac{\vec{U}}{\mathbb{U}} \\
\frac{\vec{J}}{\Delta}\end{array}$} & 3 & $287.56 \pm 7.67^{\mathrm{a}, 1}$ & $291.34 \pm 10.48^{\text {a, } 1}$ & $291.21 \pm 7.88^{\mathrm{a}, 1}$ & $184.06 \pm 2.12^{b, 1}$ & $185.03 \pm 5.60^{\mathrm{b}, 1}$ \\
\hline & 6 & $287.20 \pm 3.94^{\mathrm{a}, 1}$ & $287.32 \pm 4.11^{\mathrm{a}, 1}$ & $287.78 \pm 7.91^{\text {a, } 1}$ & $176.0 \pm 2.44^{\mathrm{c}, 2}$ & $196.82 \pm 18.54^{\mathrm{b}, 1}$ \\
\hline & 9 & $286.39 \pm 4.08^{\mathrm{a}, 1}$ & $290.96 \pm 5.94^{\mathrm{a}, 1}$ & $290.03 \pm 6.05^{\mathrm{a}, 1}$ & $168.91 \pm 1.03^{c, 3}$ & $199.56 \pm 16.82^{b, 1}$ \\
\hline \multirow{3}{*}{ 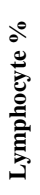 } & 3 & $62.29 \pm 1.63^{\mathrm{c}, 1}$ & $62.53 \pm 0.96^{\mathrm{c}, 1}$ & $61.55 \pm 1.40^{c, 1}$ & $73.55 \pm 0.96^{\mathrm{b}, 3}$ & $76.04 \pm 1.57^{\mathrm{a}, 1}$ \\
\hline & 6 & $60.79 \pm 2.43^{c, 1}$ & $62.24 \pm 2.09^{\mathrm{c}, 1}$ & $61.20 \pm 1.07^{\mathrm{c}, 1}$ & $77.97 \pm 0.57^{\mathrm{a}, 2}$ & $71.15 \pm 0.67^{b, 2}$ \\
\hline & 9 & $62.50 \pm 0.93^{c, 1}$ & $61.19 \pm 1.25^{\mathrm{d}, 1}$ & $62.23 \pm 2.02^{\mathrm{c}, \mathrm{d}, 1}$ & $83.40 \pm 0.40^{a, 1}$ & $68.56 \pm 0.19^{b, 3}$ \\
\hline \multirow{3}{*}{$\sum_{3}^{n}$} & 3 & $4.67 \pm 0.09^{b, 2}$ & $4.69 \pm 0.07^{b, 2}$ & $4.78 \pm 0.10^{\text {a, } 1}$ & $3.23 \pm 0.03^{\mathrm{d}, 1}$ & $3.60 \pm 0.03^{c, 3}$ \\
\hline & 6 & $4.86 \pm 0.14^{\mathrm{a}, 1}$ & $4.73 \pm 0.13^{b, 1,2}$ & $4.79 \pm 0.07^{\mathrm{a}, \mathrm{b}, 1}$ & $2.75 \pm 0.02^{\mathrm{d}, 2}$ & $3.89 \pm 0.03^{c, 2}$ \\
\hline & 9 & $4.71 \pm 0.04^{b, 2}$ & $4.82 \pm 0.09^{\mathrm{a}, 1}$ & $4.76 \pm 0.11^{\mathrm{a}, \mathrm{b}, 1}$ & $2.25 \pm 0.01^{\mathrm{d}, 3}$ & $4.06 \pm 0.009^{\mathrm{c}, 1}$ \\
\hline \multirow{3}{*}{$\sum_{\tilde{*}}^{u}$} & 3 & $6.04 \pm 0.10^{\mathrm{a}, 1}$ & $6.01 \pm 0.09^{\mathrm{a}, 1}$ & $6.03 \pm 0.08^{a, 1}$ & $4.16 \pm 0.12^{c, 1}$ & $4.41 \pm 0.25^{\mathrm{b}, 3}$ \\
\hline & 6 & $6.08 \pm 0.13^{\mathrm{a}, 1}$ & $6.11 \pm 0.15^{\mathrm{a}, 1}$ & $6.08 \pm 0.16^{\mathrm{a}, 1}$ & $3.41 \pm 0.10^{c, 2}$ & $4.71 \pm 0.15^{\mathrm{b}, 2}$ \\
\hline & 9 & $6.11 \pm 0.09^{\mathrm{a}, 1}$ & $6.08 \pm 0.16^{\mathrm{a}, 1}$ & $6.03 \pm 0.11^{\mathrm{a}, 1}$ & $3.00 \pm 0.05^{\mathrm{c}, 3}$ & $4.94 \pm 0.13^{b, 1}$ \\
\hline
\end{tabular}

$\mathrm{MCV}$, mean corpuscular volume; WBCs, white blood cells; RBCs, red blood cells.

$>$ Values are expressed as mean \pm S.D, $n=8$

$>$ There was no significant difference between means have the same alphabetical superscripts (a, b, c, d and e) in the same row.

$>$ There was no significant difference between means have the same numerical value superscripts $(1,2,3)$ in the same column.

As shown in table 3; the current results revealed that, MTX $\left(\mathrm{G}_{4}\right)$ caused a significant increase in MDA level indicator of lipid peroxidation in liver tissue. This was accompanied with a significant decrease in GSH concentration. This observation may be explained as; methotrexate is a pro-drug which has to be metabolically activated to exert its cytotoxic effect. During this activated state, free radicals are generated which can suppress the release and availability of intracellular antioxidant enzymes. Methotrexate is capable of generating potential toxic reactive oxygen species during its metabolism in the cell and thus the pro-oxidantsantioxidant balance that is usually maintained in a normal cell can be shifted towards the pro- 
oxidants following MTX metabolism (Vezmar, et al., 2003). In addition, MTX and its toxic known metabolite accumulates in the liver tissue and its long-lasting effects can be attributed to MTX persistence in the cells and its strong affinity for cellular macromolecules and membranes (Rossato et al., 2013).

Table (3): GSH (mg/g tissue) and MDA (nmole/mg tissue) concentration in liver in the studied rats groups:

\begin{tabular}{|c|c|c|c|c|c|c|}
\hline \multirow{2}{*}{ 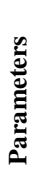 } & \multirow{2}{*}{$\begin{array}{l}\frac{n}{0} \\
\frac{0}{2}\end{array}$} & \multicolumn{5}{|c|}{ Groups } \\
\hline & & $\begin{array}{l}\text { Healthy control } \\
\text { (G1) }\end{array}$ & $\begin{array}{c}\text { Saline + DMSO } \\
\text { (G 2) }\end{array}$ & $\begin{array}{l}\text { PP group } \\
\text { (G 3) }\end{array}$ & $\begin{array}{l}\text { MTX group } \\
\text { (G4) }\end{array}$ & $\begin{array}{c}\text { MTX + PP } \\
\text { group } \\
\text { (G5) }\end{array}$ \\
\hline \multirow{3}{*}{ 危 } & 3 & $4.26 \pm 0.27^{c, 1}$ & $4.40 \pm 0.16^{\mathrm{c}, 1}$ & $4.14 \pm 0.30^{\mathrm{c}, 1}$ & $11.56 \pm 0.26^{\mathrm{a}, 3}$ & $10.75 \pm 0.36^{b, 1}$ \\
\hline & 6 & $4.27 \pm 0.27^{\mathrm{c}, 1}$ & $4.22 \pm 0.24^{c, 1}$ & $4.03 \pm 0.25^{c, 1}$ & $15.74 \pm 1.74^{\mathrm{a}, 2}$ & $10.06 \pm 0.44^{b, 2}$ \\
\hline & 9 & $4.24 \pm 0.06^{\mathrm{c}, 1}$ & $4.24 \pm 0.13^{\mathrm{c}, 1}$ & $3.93 \pm 0.25^{\mathrm{c}, 1}$ & $24.81 \pm 2.38^{\mathrm{a}, 1}$ & $9.59 \pm 0.12^{b, 3}$ \\
\hline \multirow{3}{*}{ 芯 } & 3 & $75.77 \pm 1.83^{\mathrm{a}, 1}$ & $75.86 \pm 2.65^{\mathrm{a}, 1}$ & $74.72 \pm 1.76^{\mathrm{a}, 1}$ & $50.73 \pm 0.30^{c, 1}$ & $55.85 \pm 2.83^{b, 3}$ \\
\hline & 6 & $76.11 \pm 1.09^{\mathrm{a}, 1}$ & $74.27 \pm 1.98^{a, 1}$ & $75.75 \pm 2.39^{\mathrm{a}, 1}$ & $46.40 \pm 3.12^{\mathrm{c}, 2}$ & $60.37 \pm 1.92^{\mathrm{b}, 2}$ \\
\hline & 9 & $75.69 \pm 1.20^{\mathrm{a}, 1}$ & $75.06 \pm 2.15^{\mathrm{a}, 1}$ & $74.32 \pm 1.05^{\mathrm{a}, 1}$ & $34.48 \pm 2.38^{c, 3}$ & $67.34 \pm 1.29^{\mathrm{b}, 1}$ \\
\hline
\end{tabular}

MDA, malondialdehyde; GSH, reduced glutathione.

$>$ Values are expressed as mean \pm S.D, $n=8$

$>$ There was no significant difference between means have the same alphabetical superscripts (a, b, c, d and e) in the same row.

$>$ There was no significant difference between means have the same numerical value superscripts $(1,2,3)$ in the same column.

It is well known that, liver is the most sensitive organ to pre-oxidative damage because it is rich in oxidizable substances. The increment of the oxidative stress on the cells of the liver and the consequent decrease in the antioxidant ability of the cells result in the occurrence of aggressive cellular damage to the liver cells with destruction of their membranes and the release of the enzymes into the blood stream. Liver is the major site for synthesis of GSH and detoxification of different drugs and xenobiotics. GSH is one of the most important molecules in the cellular defense against chemically reactive toxic compounds or oxidative stress (Seven et al., 2004). 
In addition, Vardi et al. (2010) suggested that, MTX could decrease the availability of NADPH in cells. Normally, NADPH is used by glutathione reductase to maintain the reduced state of cellular glutathione (GSH).

MDA is the breakdown product of most important chain reactions leading to oxidation of polyunsaturated fatty acids and therefore serves as a reliable biomarker of oxidative stressmediated lipid peroxidation (Ozguner et al., 2005).

Previous studies; Coleshowers, et al. (2010) and Sener et al. (2006) reported that MTX administration caused a significant increase in the level of MDA concluding that lipid peroxidation, mediated by oxygen free radicals, is believed to be an important cause of destruction and damage to cell membranes and has been suggested to be a contributing factor to the development of methotrexate-mediated tissue damage. The same observation were obtained by Kovacic and Somanathan (2008) and Jwied et al. (2009) they reported that rats treated with MTX resulted in a significant increase in hepatic lipid peroxidation measured by the amount of MDA formed, associated with significant decrease in the liver tissue GSH levels compared to control group. The oral administration of propolis to MTX toxicated rats $\left(\mathrm{G}_{5}\right)$ seem to reduce liver MDA and increase GSH levels. The effect of propolis was more pronounced in 9 weeks. These findings demonstrate the ability of propolis to has marked hepato-protective potential because of its composition of vitamins, minerals and bioflavonoids (Badr et al., 2011).

The present data is in consistent with that reported by Çetin et al. (2011) and Badr et al. (2011) they found that, co-administration of propolis with MTX, lowered MDA formation in the rat liver tissue. Study by Ali et al. (2014) demonstrated the protective effect of chrysin as a component of propolis against MTX-induced hepatotoxicity and showed that the chrysin was capable of enhancing the therapeutic index of MTX when the two were administered simultaneously. Chrysin co-administration reversed increase in MDA content and increased GSH concentration.

With regard to MTX hepatotoxicity, marked by elevated serum aminotransferase activities, ALP activity and total bilirubin concentration in the liver of MTX treated rats as compared to control rats. MTX treatment for nine weeks possesses maximum damage, table 4 . With respect to total bilirubin there was a significant increase in MTX group after 9 weeks compared to control group and no significant change in 3 and 6 weeks. It has been postulated that, AST and ALT are cytosolic enzymes of the hepatocytes. They are involved in the breakdown of amino acids into $\alpha$-keto acids. Any increase in their activities reflects a leakage in plasma membrane permeability, which in turn, is associated with cell death. They are best indicators of liver necrosis (Abdel-Ghaffar et al., 2013).

The presence of higher activity of MTX poly glutamates inside liver cells causes a longer intracellular presence of the drug, and this has been suggested as a mechanism for MTX hepatotoxicity. In addition, oxygen radicals and hydrogen peroxides have been associated with the many side effects of MTX and these free radicals trigger cell damage through binding to 
cellular macromolecules, particularly membrane lipids leading to releasing of AST and ALT from cells to serum (Vardi et al., 2010). The present results in accordance with Jwied et al. (2009), Badr et al. (2011) and Ali et al. (2014) they found that MTX group caused liver dysfunction that appeared by a significant increase in ALT and AST activities which could be due to liver damage, mild necrosis and inflammation. In contrast to our results, Abdul-Wahab and Abdul Jalil (2012) showed no statistical significant differences in AST, ALT activities and bilirubin level in methotrexate treated group, this may be due to administration of methotrexate for short duration or may need high dose to produce change in the level of these enzymes, while the level of ALP was decreased. Propolis reversed the adverse effect of MTX on liver hepatotoxicity and decreased the levels of serum AST, ALT and ALP activities and total bilirubin concentration.

Table (4): Serum ALT (U/L), AST (U/L), ALP (U/L) activities and total bilirubin concentration (mg/dl) in the studied rats groups:

\begin{tabular}{|c|c|c|c|c|c|c|}
\hline \multirow{2}{*}{ 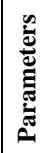 } & \multirow{2}{*}{$\frac{n}{d}$} & \multicolumn{5}{|c|}{ Groups } \\
\hline & & $\begin{array}{l}\text { Healthy control } \\
\text { (G1) }\end{array}$ & $\begin{array}{c}\text { Saline + } \\
\text { DMSO (G 2) }\end{array}$ & $\begin{array}{l}\text { PP group } \\
\quad(\text { G 3) }\end{array}$ & $\begin{array}{l}\text { MTX group } \\
\text { (G4) }\end{array}$ & $\begin{array}{c}\text { MTX + PP group } \\
\text { (G5) }\end{array}$ \\
\hline \multirow{3}{*}{$\frac{5}{4}$} & 3 & $33.40 \pm 1.67^{c, 1}$ & $33.30 \pm 1.57^{\mathrm{c}, 1}$ & $33.21 \pm 2.16^{\mathrm{c}, 1}$ & $60.20 \pm 0.64^{\mathrm{a}, 3}$ & $52.53 \pm 1.83^{\mathrm{b}, 1}$ \\
\hline & 6 & $33.17 \pm 1.78^{\mathrm{c}, 1}$ & $33.05 \pm 2.02^{c, 1}$ & $32.46 \pm 1.69^{c, 1}$ & $72.50 \pm 2.93^{a_{,} 2}$ & $47.35 \pm 2.41^{\mathrm{b}, 2}$ \\
\hline & 9 & $34.87 \pm 1.45^{\mathrm{c}, 1}$ & $33.34 \pm 1.14^{\mathrm{c}, 1}$ & $33.88 \pm 2.13^{\mathrm{c}, 1}$ & $86.22 \pm 1.24^{\mathrm{a}, 1}$ & $42.20 \pm 1.83^{\mathrm{b}, 3}$ \\
\hline \multirow{3}{*}{$\frac{5}{4}$} & 3 & $21.40 \pm 1.46^{\mathrm{c}, 1}$ & $21.95 \pm 0.95^{\mathrm{c}, 1}$ & $21.76 \pm 1.61^{\mathrm{c}, 1}$ & $51.35 \pm 0.66^{\mathrm{a}, 3}$ & $42.61 \pm 2.22^{\mathrm{b}, 1}$ \\
\hline & 6 & $22.03 \pm 1.43^{\mathrm{c}, 1}$ & $21.82 \pm 1.04^{\mathrm{c}, 1}$ & $21.68 \pm 1.55^{\mathrm{c}, 1}$ & $64.63 \pm 3.37^{\mathrm{a}, 2}$ & $36.78 \pm 3.22^{\mathrm{b}, 2}$ \\
\hline & 9 & $21.81 \pm 1.04^{\mathrm{c}, 1}$ & $22.66 \pm 0.82^{\mathrm{c}, 1}$ & $22.03 \pm 0.58^{\mathrm{c}, 1}$ & $76.49 \pm 2.64^{\mathrm{a}, 1}$ & $33.12 \pm 1.32^{\mathrm{b}, 3}$ \\
\hline \multirow{3}{*}{$\frac{3}{2}$} & 3 & $85.64 \pm 3.17^{\mathrm{c}, 1}$ & $86.58 \pm 2.83^{c, 1}$ & $86.03 \pm 2.37^{\mathrm{c}, 1}$ & $116.84 \pm 1.46^{\mathrm{a}, 3}$ & $105.27 \pm 1.81^{\mathrm{b}, 1}$ \\
\hline & 6 & $87.41 \pm 2.25^{\mathrm{c}, 1}$ & $86.75 \pm 2.98^{\mathrm{c}, 1}$ & $85.91 \pm 2.57^{\mathrm{c}, 1}$ & $124.80 \pm 3.11^{\mathrm{a}, 2}$ & $100.31 \pm 1.01^{b, 2}$ \\
\hline & 9 & $86.63 \pm 2.08^{c, 1}$ & $86.96 \pm 1.64^{\mathrm{c}, 1}$ & $85.78 \pm 2.38^{\mathrm{c}, 1}$ & $135.96 \pm 3.12^{\mathrm{a}, 1}$ & $96.46 \pm 2.05^{\mathrm{b}, 3}$ \\
\hline \multirow{3}{*}{ 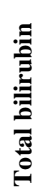 } & 3 & $0.52 \pm 0.01^{\mathrm{a}, 1}$ & $0.52 \pm 0.03^{\mathrm{a}, 1}$ & $0.48 \pm 0.01^{\mathrm{b}, 1}$ & $0.52 \pm 0.03^{\mathrm{a}, 2}$ & $0.54 \pm 0.04^{\mathrm{a}, 1}$ \\
\hline & 6 & $0.51 \pm 0.02^{\mathrm{b}, 1}$ & $0.52 \pm 0.02^{\mathrm{a}, 1}$ & $0.48 \pm 0.02^{b, 1}$ & $0.51 \pm 0.03^{b, 2}$ & $0.53 \pm 0.02^{a, 1}$ \\
\hline & 9 & $0.52 \pm 0.01^{\mathrm{b}, 1}$ & $0.52 \pm 0.01^{\mathrm{b}, 1}$ & $0.48 \pm 0.02^{c, 1}$ & $0.60 \pm 0.01^{\mathrm{a}, 1}$ & $0.53 \pm 0.02^{b, 1}$ \\
\hline
\end{tabular}

AST, aspartate aminotransferase; ALT, alanine aminotransferase; ALP, alkaline phosphatase.

$>$ Values are expressed as mean \pm S.D, $\mathrm{n}=8$

$>$ There was no significant difference between means have the same alphabetical superscripts (a, b, c, d and e) in the same row.

$>$ There was no significant difference between means have the same numerical value superscripts $(1,2,3)$ in the same column. 
Such improvements support the hepato-protective effect of propolis. This might be due to the accelerated regeneration of hepatic parenchymal cells under the influence of various bioactive compounds of propolis like flavonoid and their esters. They prevent membrane fragility and subsequently decreased the leakage of marker enzymes into the circulation.

Previous results recorded that the treatment with propolis significantly decreased the activities of serum ALT, AST and ALP suggesting its hepato-protective potential (Badr et al., 2011 and Saleh, 2012). It seems that, MTX administered rats $\left(\mathrm{G}_{4}\right)$ showed a significant increase in serum urea and creatinine and a significant decrease in serum uric acid level $(p<0.05)$ as compared to control group; table 5. There was a significant progressive change over the duration of administration as compared to the 3 and 6 weeks' time intervals. The present results indicated that nephrotoxicity is an important side-effect of this drug and that administration of a high-dose of MTX may also results in acute renal failure possibly due to precipitation of MTX and/or MTX metabolite (7-OH-MTX) in the renal tubules. This nephrotoxicity leads to delayed MTX elimination. The decreased output of uric acid is a direct consequence of decreased purine catabolism, and hence an indication of a possible treatment-related decrease in nucleic acid turnover (Van den bongard et al., 2001). Recent studies; Pinheiro et al. (2010) reported that MTX administration significantly increased the serum levels of urea and decrease uric acid levels in the serum of MTX- group suggesting a nephrotoxic condition. From, the present results it's clear that after 9 weeks of propolis consumption $\left(\mathrm{G}_{5}\right)$ there were a significant decrease in the elevated levels of serum urea and creatinine compared to MTX-treated group $\left(\mathrm{G}_{4}\right)$.

Table (5): Serum urea (mg/dl), creatinine (mg/dl) and uric acid (mg/dl) levels in the studied rats groups:

\begin{tabular}{|c|c|c|c|c|c|c|}
\hline & $\frac{\mathscr{\theta}}{\frac{\pi}{0}}$ & $\begin{array}{c}\text { Healthy control } \\
\text { (G1) }\end{array}$ & $\begin{array}{c}\text { Saline + DMSO } \\
\text { (G 2) }\end{array}$ & $\begin{array}{l}\text { PP group } \\
\text { (G 3) }\end{array}$ & $\begin{array}{l}\text { MTX group } \\
\text { (G4) }\end{array}$ & $\begin{array}{c}\text { MTX + PP } \\
\text { group } \\
\text { (G5) }\end{array}$ \\
\hline \multirow{3}{*}{ \$ } & 3 & $23.82 \pm 1.67^{\mathrm{d}, 1}$ & $24.14 \pm 1.87^{\mathrm{d}, 1}$ & $27.63 \pm 1.91^{\mathrm{c}, 1}$ & $49.46 \pm 4.11^{\mathrm{a}, 3}$ & $42.66 \pm 0.82^{b, 1}$ \\
\hline & 6 & $23.75 \pm 2.02^{c, 1}$ & $24.31 \pm 1.47^{\mathrm{c}, 2}$ & $24.56 \pm 2.82^{c, 1}$ & $52.48 \pm 1.83^{\mathrm{a}, 2}$ & $37.69 \pm 2.56^{\mathrm{b}, 2}$ \\
\hline & 9 & $25.13 \pm 0.81^{c, 1}$ & $25.66 \pm 1.86^{\mathrm{c}, 1,2}$ & $24.56 \pm 1.12^{\mathrm{c}, 1}$ & $60.42 \pm 1.67^{\mathrm{a}, 1}$ & $33.83 \pm 2.34^{b, 3}$ \\
\hline \multirow{3}{*}{ } & 3 & $0.95 \pm 0.03^{\mathrm{c}, 1}$ & $0.97 \pm 0.04^{c, 1}$ & $0.95 \pm 0.02^{\mathrm{c}, 2}$ & $1.58 \pm 0.01^{\mathrm{a}, 2}$ & $1.47 \pm 0.02^{b, 1}$ \\
\hline & 6 & $0.97 \pm 0.02^{c, 1}$ & $0.96 \pm 0.03^{c, 1}$ & $0.96 \pm 0.02^{c, 1,2}$ & $1.73 \pm 0.19^{\mathrm{a}, 2}$ & $1.25 \pm 0.05^{\mathrm{b}, 2}$ \\
\hline & 9 & $0.97 \pm 0.01^{\mathrm{c}, 1}$ & $0.97 \pm 0.02^{c, 1}$ & $0.99 \pm 0.04^{c, 1}$ & $2.85 \pm 0.26^{\mathrm{a}, 1}$ & $1.11 \pm 0.02^{\mathrm{b}, 3}$ \\
\hline \multirow{3}{*}{ } & 3 & $4.78 \pm 0.15^{\mathrm{a}, 1}$ & $4.87 \pm 0.16^{\mathrm{a}, 1}$ & $4.86 \pm 0.10^{\mathrm{a}, 1}$ & $4.02 \pm 0.01^{\mathrm{c}, 1}$ & $4.19 \pm 0.10^{b, 3}$ \\
\hline & 6 & $4.89 \pm 0.08^{\mathrm{a}, 1}$ & $4.88 \pm 0.14^{\mathrm{a}, 1}$ & $4.86 \pm 0.16^{\mathrm{a}, 1}$ & $3.23 \pm 0.08^{c, 2}$ & $4.21 \pm 0.06^{\mathrm{b}, 2}$ \\
\hline & 9 & $4.75 \pm 0.18^{a, 1}$ & $4.74 \pm 0.13^{\mathrm{a}, 1}$ & $4.82 \pm 0.11^{\mathrm{a}, 1}$ & $2.51 \pm 0.03^{c, 3}$ & $4.37 \pm 0.06^{\mathrm{b}, 1}$ \\
\hline
\end{tabular}

\footnotetext{
$>$ Values are expressed as mean \pm S.D, $n=8$

$>$ There was no significant difference between means have the same alphabetical superscripts (a, b, c, d and e) in the same row.

$>$ There was no significant difference between means have the same numerical value superscripts $(1,2,3)$ in the same column.
} 
Results of Conlon and Law (2004) and Uz et al. (2005) revealed that administration of caffeic acid phenethyl ester (CAPE) a component of propolis may have protective potential in the pathogenesis of MTX-induced oxidative renal damage. In the same line Badr et al. (2011) showed that group treated with MTX revealed increase in serum creatinine level and While propolis administration revealed amelioration toward the normal control group.

The MTX-induced changes in oxidative damage markers detected in the present study by biochemical analysis were in parallel to the alterations obtained from histological observations of liver specimens. MTX-induced structural damage to the liver, such as hepatic portal tract dilatation, inflammatory cell infiltration and fibrosis fig. 2, 3 and 4. MTX treatment showed variable degrees of morphological and pathological changes. These changes were gradual and progressive after 3 and 6 weeks of injections, and extended to 9 weeks of injections which showed more damage. Similar histopathological results have been previously reported by a multitude of MTX studies using in vivo models. Akbulut et al., (2014) observed focal areas of necrosis in livers of rats exposed to MTX, and Jwied et al., (2009) showed degenerative changes in liver tissues of MTX-administered rats.

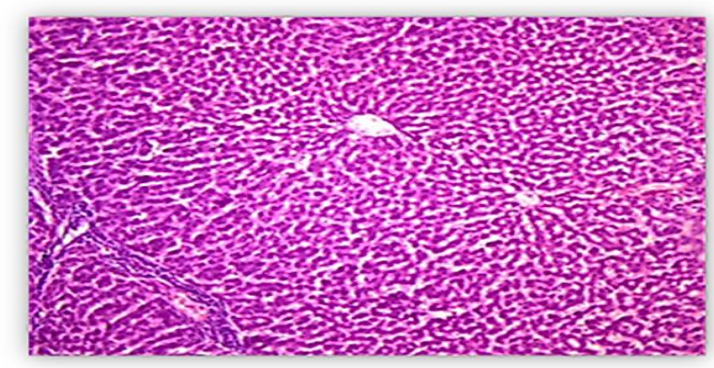

Figure (1) Normal histological appearance of liver in (control group). H\&E (x200).

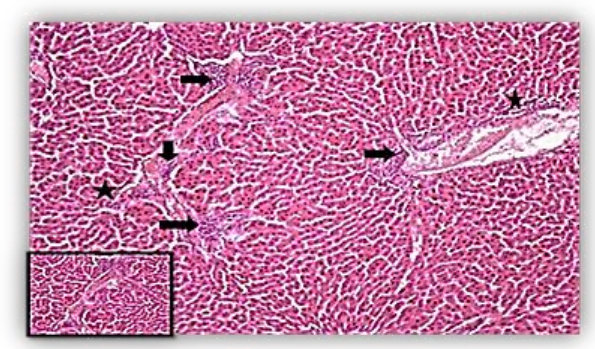

Figure (2) Liver tissue of MTX group (after 3 weeks) showed multifocal portal tract expansion by mononuclear inflammatory infiltrate (arrows) and interface hepatitis (stars). (H \& E 200) The inset showed a higher magnification (H \&E x 400).

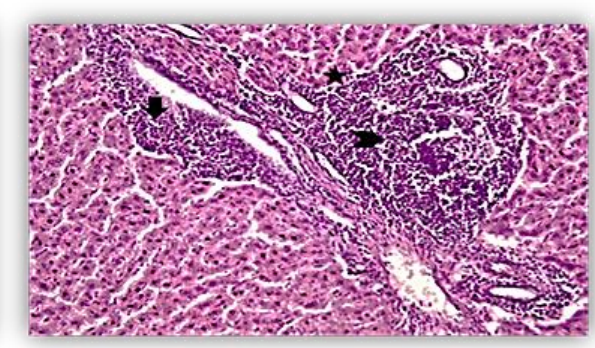

Figure (3) Liver tissue of MTX group (after 6 weeks) showed marked portal tract expansion by severely dense mononuclear inflammatory infiltrate (arrows), lymphoid aggregate formation (chevron) and interface hepatitis (stars). Moderate fibrosis could be seen (H \&E 200). 


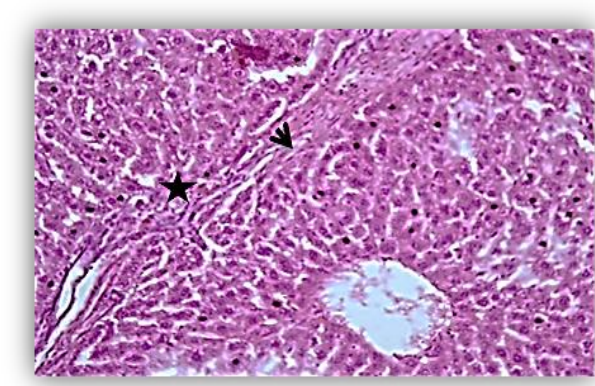

Figure (4) Liver tissue biopsy of the MTX group (after 9 weeks) showed portal tract expansion by fibrosis with porto-portal bridging (arrow) (stage 3/6) and mild mononuclear inflammatory infiltrate and mild interface hepatitis (stars) (H\&E $\mathrm{X} 200$ ).

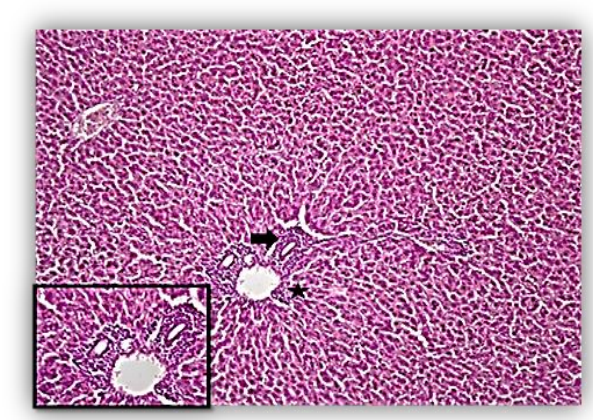

Figure (6) Liver tissue of MTX + PP group (after 6 weeks) showed moderate portal tract expansion by mononuclear inflammatory infiltrate (arrows) and interface hepatitis (stars). ( $\mathrm{H} \& \mathrm{E} \quad 200$ ) higher magnification (H \&E x 400).

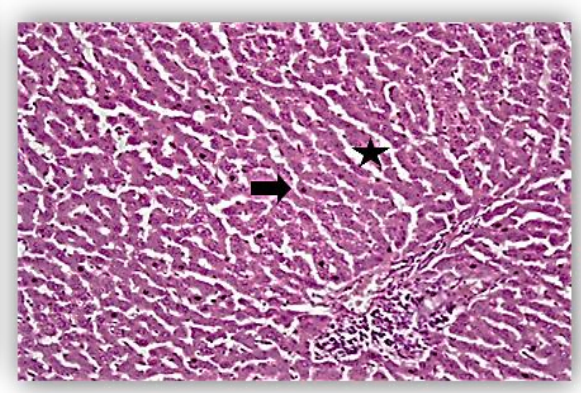

Figure (5) Liver tissue of MTX + PP group (after 3 weeks) showed mild portal tract expansion by mild mononuclear inflammatory infiltrate (arrows) and interface hepatitis (stars). (H \&E 200).

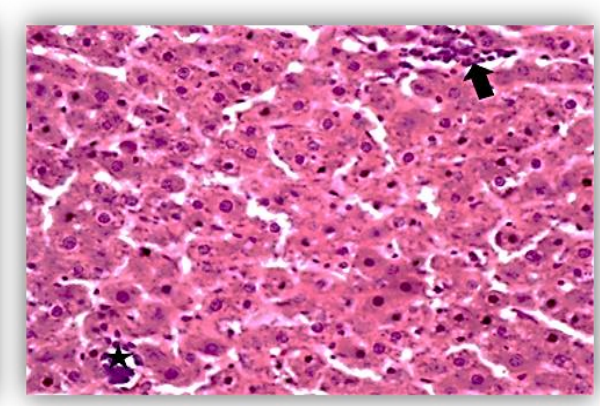

Figure (7) Liver tissue of MTX + PP group (after 9 weeks) showed minimal portal tract expansion by mononuclear inflammatory infiltrate (arrows) and spotty parenchymal inflammation (star)(H \& E x 400 ) 
The histopathological data proposed that, propolis was able to improve the MTXrelated histopathological damage induced in liver tissues, suggesting its potential benefit as adjunct protective agents fig. 5,6,7.

\section{Conclusion}

Results suggest that propolis administration able to ameliorate the MTX induced oxidative damage observed in blood, kidney and liver. It may alleviate oxidative stress by synergistic action of its constituents that increase the endogenous antioxidant status, protecting cells against free-radical damage, thus enhance the therapeutic effectiveness of MTX with better tolerance of the drug.

\section{References}

Abdel-Ghaffar, F.R.; El-Elaimy, I.A.; El-Dougdoug,K. and Nassar, H.I. Protective and modulatory effects of curcumin and L-carnitine against methotrexate-induced oxidative stress in albino rats, Res. J. Pharm. Biol. Chem. Sci.4:744-754 (2013).

Abdul-Wahab, F.K. and Abdul Jalil, T.K. Study of iraqi spinach leaves phytochemical and protective effects against methotrexate-induced hepatotoxicity in rats, Iraqi J Pharm Sci. 21(2): 8-17(2012).

Abu Aita, N.A.; Hashesh, M.A. and Mohamed, A.H. Clinicopathological and cytogenetic studies on the ameliorative.effect of propolis against profenofos toxicity in rats, G.V. 9 (6): 669-682 (2012).

Akbulut, S.; Eris,C. and Otan, E. Cytoprotective effects of amifostine, ascorbic acid and Nacetylcysteine against methotrexate-induced hepatotoxicity in rats, World J. Gastroenterol. 20(29): 10158-10165 (2014).

Ali, N.; Rashid, S.; Nafees, S.; Hasan, S.K. and Sultana, S. Beneficial effect of chrysin against mtx-induced hepatotoxicity via attenuation of oxidative stress and apoptosis, Mol. cell. biochem. 385:215-223 (2014).

Badr, M.O.; Edrees, N.M.M.; Abdallah, A.A.M.; Hashem, M.A.; El-Deen, N.A. ; NeamatAllah, A.N.F. and Ismail, H.T.H. Propolis protects against methotrexate induced hepatorenal dysfunctions during treatment of ehrlich carcinoma, J. Am. Sci. 7(12):313-319 (2011).

Bhadauria M, Nirala KS, Shukla S. Multiple treatment of propolis extract ameliorates carbon tetrachloride induced liver injury in rats, Food Chem. Toxicol. 46; 2703-12 (2008). 
Belfield, A. and Goldberg D.M. Revised assay for serum phenyl phosphatase activity using 4aminoantipyrine, Enzyme, 12, 561-573 (1971).

Beutler, E.; Duron, O. and Kelly, B.M. Improved method for the determination of blood glutathione, J. Lab. Clin. Med. 61:882-888 (1963).

Çetin,A.; Kaynar, L.; Kocyigit, I. Hacioglu, Recep Saraymen, S.K.; Ozturk, A. Sari, I. and Sagdic, O. (2008): Role of grape seed extract on methotrexate induced oxidative stress in rat liver, Am. J. Chin. Med.36:861-872 (2008).

Çetin, A.; Kaynar, L.; Eser, B. ; Karadag, C.; Saraymen, B.; Öztürk, A.; Koçyiğit, I.; Hacıoğlu, S.K.; Çiçek, B. and Silici, S. Beneficial effects of propolis on methotrexate-induced liver injury in rats, A.O.T.44:18-23(2011).

Coleshowers, C.L; Oguntibeju, O.O; Ukpong, M. and Truter, E.J. Effects of methotrexate on antioxidant enzyme status in a rodent model, Medical Technology SA. 24 (1):5-9 (2010).

Conlon, B.A. and Law, W.R. Macrophages are a source of extracellular adenosine deaminase2 during inflammatory responses, Clin Expm.Immunol.138: 14-20 (2004).

DeBruyne, L. and Pinna, K. Nutrition for health and healthcare, fifth edition, Cengage Learning, USA. pp.418 (2013).

El-Masry, T.A; Emara, A.M. and El-Shitany, N.A.. Possible protective effect of propolis against lead induced neurotoxicity in animal model, J. Evol. Biol. Res. 3(1):4-11(2011).

Farooqui, T. and Farooqui, A.A. Molecular mechanism underlying the therapeutic activities of propolis, Current Nutr. \& Food Sci.6:1-14(2010).

Gochman, N. and Schmitz, J.M. Automated determination of uric acid, with use of a uricaseperoxidase system, J. Clin. Chem. 17(12):1154-1159 (1971).

Henry, J.B. Clinical diagnosis and management by laboratory method. W.B. saunders Co., Philadelphia, PP. 361-365(1974 a).

Henry, J.B. Clinical Diagnosis and Management by Laboratory Method. W.B. Saunders Co., Philadelphia, PP.332 - 335(1974 b).

Juntti-Patinen, L.; Kuitunen, T.; Pere, P. and Neuvonen, P.J. Drug-related visits to a district hospital emergency room, Basic Clin. Pharmacol. Toxicol.98:212-7 (2007).

Jwied, A.H. Hepatoprotective Effect of the Aqueous Extract of Camellia sinensis against Methotrexate-induced Liver Damage in Rats, Iraqi J. Pharm. Sci.18 (2):73-79 (2009). 
Krajinovic, M. and Moghrabi, A. Pharmacogenetics of methotrexate. Pharmacogenomics, 5, 819- 834 (2004).

Kędzia, B. Chemical composition of Polish propolis. Part 2. New study, Post. Fitoter. 2,122128 (2009).

Kovacic, P. and Somanathan, R. Unifying mechanism for eye toxicity: electron transfer, reactive oxygen species, antioxidant benefits, cell signaling and cell membranes, Cell Membr. Free Radic. Res. 2; 56-69 (2008).

Malloy, H.T. and Evelyn, K.A. The determination of bilirubin with the photoelectric colorimeter. J. Biol. Chem. 119:481-490 (1937).

Mohamed, A.M. and Metwally, N.S.Antiafla-toxigenic activities of some plant aqueous extracts against aflatoxin- $\mathrm{B}_{1}$ induced renal and cardiac damage, J. Pharmacol. Toxicol. 4(1):116 (2009).

Najafi, M.F.; Vahedy, F.; Seyyedin, M.; Jomehzadeh, H.R. and Bozary, K. Effect of the water extracts of propolis on stimulation and inhibition of different cells. Cytotechnolo.54:4956 (2007).

National Research Council, NRC. Nutrient requirements of laboratory animals. $4^{\text {th }}$ revised edition. National Academy Press, Washington, D.C., chapter (2):PP. 11-79 (1995).

Moreira, L.L.; Dias, T. et al. Propolis influence on erythrocyte membrane disorder (hereditary spherocytosis): a first approach, Food Chem. Toxicol. 49:520-526 (2011).

Ohkawa, H.; Ohishi, N. and Yagi, K. Assay of lipid peroxides in animal tissues by thiobarbituric acid reaction, J. Anal. Biochem. 95:351-358 (1979).

Pinheiro, F. V.; Pimentel, V. C.; Bona, K. S.; Scola, G.; Salvador, M.; Funchal, C. and Moretto, M. B. Decrease of adenosine deaminase activity and increase of the lipid peroxidation after acute methotrexate treatment in young rats: protective effects of grape seed extract, Cell Biochem. Funct. 28: 89-94 (2010).

Rock, R.C.; Walker, W.G. and Jennings, C.D. Nitrogen metabolites and renal function. In: Tietz NW, ed. Fundamentals of clinical chemistry. 3rd ed. Philadellphia: WB Saunders, PP. 669-704 (1987).

Rossato, L.G.; Costa, V.M.; Villas-Boas, V.; de Lourdes Bastos, M.; Rolo, A.; Palmeira, C. and Remião, F. Therapeutic concentrations of mitoxantrone elicit energetic imbalance in H9c2 cells as an earlier effect, Cardiovasc. Toxicol. 13(4):413-25 (2013). 
Russo A, Longo R, Vanella A. Antioxidant activity of propolis: role of caffeic acid phenethyl ester and galengin. Fitoterapia 73(1):21-9 (2002).

Sak, K. Chemotherapy and dietary phytochemical agents, Chemother. Res. Pract. 1-11(2011).

Saleh, E.M. Antioxidant effect of aqueous extract of propolis on hepatotoxicity induced by octylphenol in male rats, Acta. Toxicol. Argent. 20 (2): 68-81(2012).

Sener, G.; Eksioglu-Demiralp, E.; Cetiner, M.; Ercan, F.; Sirvancı, S. Gedik, N. and Yegen, B.C. L-Carnitine ameliorates methotrexate-induced oxidative organ injury and inhibits leukocyte death, Cell Biol. Toxicol. 22: 47-60 (2006).

Seven, A.; Guzel, S.; Seymen, O.; Civelek, S.; Bolayirli, M.; Uncu, M. and Burcak, G. Effects of vitamin E supplementation on oxidative stress in streptozotocin induced diabetic rats: Investigation of liver and plasma, J. Yonsei Med. 45:703-710 (2004).

Sforcin, J.M.; Novelli, E.L.B. and Funari, S.R.C. Seasonal effect of brazilian propolis on seric biochemical variables, J. Venom. Anim. Toxins. 8: 244-254. (2002).

Sforcin, J.M. and Bankova, V. Propolis: Is there a potential for the development of new drugs? (Review), J. Ethnopharmacol. 133:253-260 (2011).

Tatli Seven, P.; Yılmaz, S.; Seven, İ.; Çerçi, İ.H.; Azman, M.A. and Yılmaz, M. The effect of propolis on selected blood indicators and antioxidant enzyme activities in broilers under heat stress, Acta Vet. Brno.78: 75-83(2009).

Tobacco, A.; Meiattini, F.; Moda, E. and Tarii, P. Simplified enzymic/colorimetric serum urea nitrogen determination, J. Clin. Chem. 25: 336-337 (1979).

Ulrich, C.M; Yasui, Y.; Storb, R.; Schubert, M.M.; Wagner, J.L.; Bigler, J., et al. Pharmacogenetics of methotrexate: Toxicity among marrow transplantation patients varies with the methylenetetrahydrofolate reductase c677t polymorphism. Blood 98: 231-234 (2001).

Uz, E.; Oktem, F.; Yılmaz, H.R.; Uzar, E. and Ozguner, F. The activities of purinecatabolizing enzymes and the level of nitric oxide in rat kidneys subjected to methotrexate: Protective effect of caffeic acid phenethyl ester, Molecul. and Cell. Biochem. 277: 165-170 (2005).

Vardi, N.; Parlakpinar, H.; Cetin, A.; Erdogan, A. and Ozturk, I.C. Protective effect of $\beta$ carotene on methotrexate induced oxidative liver damage, Toxicol. Pathol. 38: 592-597(2010).

Van den bongard, H.J.G.D; Manhot, R.A.A and Beijnen, JH et al. Successful rescue with leucovorin and thymidine in a patient with high-dose methotrexate induced acute renal failure, Cancer Chemother. Pharmacol. 47:537-540 (2001).

Vezmar, S.; Becker, A.; Bode, U. and Jaehde, U. Biochemical and clinical aspects of methotrexate neurotoxicity, Chemother. 49:92-104 (2003). 


\author{
ملخص البحث باللغة العربية \\ التأثير المحن لمستخلص صمغ النحل ضد التلف التأكسى المحثث بواسطة الميثوتركسيت في الجرذان \\ فاطمه عبد الحميد خليل, أمل عشماوى أحمد, إيناس علي كامل , نورهان جمال الرحماني \\ قسم الكيمياء الحيوية و التفذية,

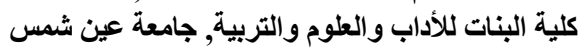

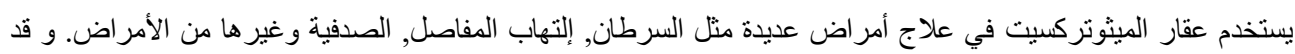

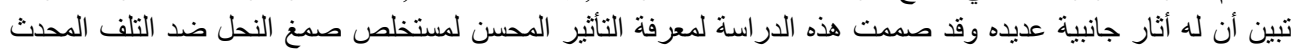

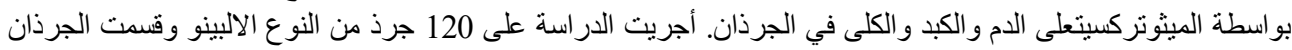

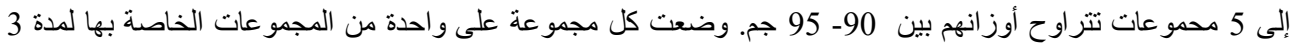

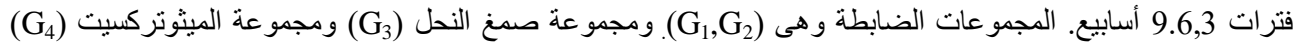

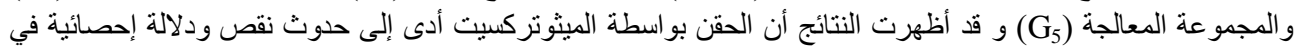

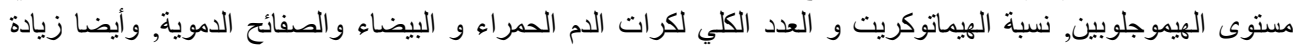

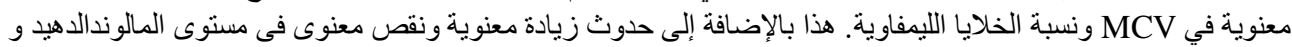

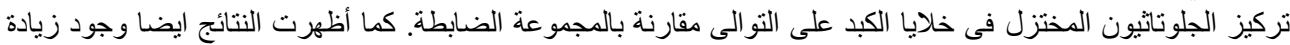

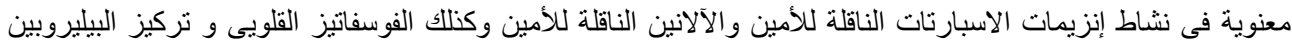

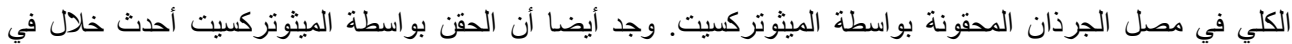

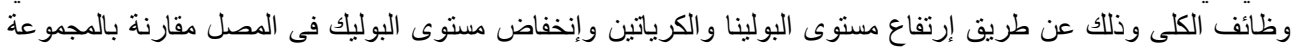

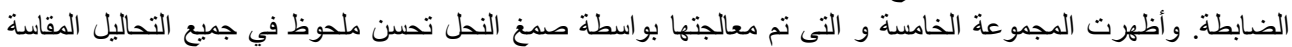

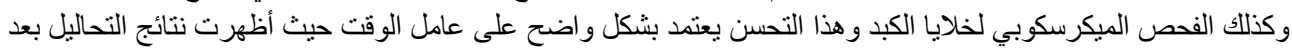

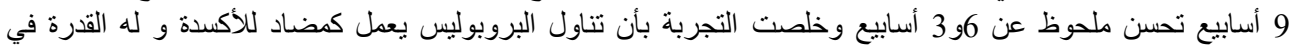

التخفيف من الأثار الجانبية لعقار الميثوتركسيت وبالتالي زيادة فعالية العلاج للمرضئ اليروبى الذين هم في إحتياج للميثوتركسيت. 